\title{
RIETUMEIROPAS VĒSTURISKĀS \\ KRIMINĀLPROCESA DOKTRĪNAS EVOLŪCIJAS \\ NEKONSEKVENCES UN PROBLĒMAS LATVIJĀ
}

\section{INCONSISTENCIES AND PROBLEMS IN THE EVOLUTION OF WESTERN EUROPE'S HISTORICAL DOCTRINE OF CRIMINAL PROCEEDINGS IN LATVIA}

\author{
Egons Rusanovs, $M g$. iur. \\ Latvijas Universitātes Juridiskās fakultātes \\ Tiesību teorijas un vēstures zinātṇu katedras doktorants
}

\section{Summary}

The principles of judicial power of the interwar period Republic of Latvia (1918-1940) after restoration of independence (1990-1991) were taken over only in part. By reforming the order of criminal procedure, the legislator did not base it on the interwar tradition of Latvian law. However, the course of the reforms in the Republic of Latvia retained the comprehension of the "previous investigation" institute, which was implemented after the Soviet occupation (1940) and unfamiliar to Continental Europe's tradition of criminal procedural rights. The classical value - "previous investigation as a part and function of the trial proceedings" - also existed in the Republic of Latvia during the interwar period. In author's opinion, maintaining such foreign matter in the reformed criminal proceedings in Latvia cannot meet the contemporary requirements and create a number of systemic problems.

Atslēgvārdi: kriminālprocesa vēsture, kriminālprocesa reformas, kontinentālās Eiropas kriminālprocesa tradīcija, padomju kriminālprocess, iepriekšējā izmeklēšana

Keywords: history of criminal proceedings, reform of criminal proceedings, tradition of criminal proceedings in Continental Europe, Soviet criminal proceedings, previous investigation

\section{Ievads}

Jāpiekrīt profesoram Jānim Lazdiṇam, ka Latvijas Republikā ir nodrošināta tiesu varas kontinuitāte. ${ }^{1}$ Tomēr jāpievienojas arī citviet viṇa starp rindām sacītajam viedoklim, ka tie tiesu varas principi, kādi pastāvēja starpkaru Latvijas Republikā (1918-1940), tikai dal̦ēji tika pārņemti pēc neatkarības atjaunošanas ("pēc neatkarības atjaunošanas de facto Latvijas Republikā tiesu vara tika atjaunota

1 Lazdiṇš J. Tiesu varas nepārtrauktība Latvijas Republikā. Priekšnoteikumi un nepieciešamība. Grām.: Nepārtrauktības doktrīna Latvijas vēstures kontekstā. Autoru kolektīvs prof. T. Jundža zinātniskā vadībā. Rīga: LZA Stratēgisko pētijumu centrs, 2017, 359. lpp. 
daudzējādā ziṇā uz tiem pašiem principiem, kas pastāvēja pirms Latvijas Republikas okupācijas"). "Vispilnīgāk Latvijas valsts gadsimtu gaitā līdz mūsdienām ir saglabājusi zvērināta advokāta tiesisko regulējumu."3 Atbilstoši profesora J. Lazdiṇa ieskatam "Latvija varēja balstīties uz starpkaru Latvijas tiesību tradīciju. [Izrādījās], ka jaunlaiku prasībām atbilstoša tiesu vara daudzējādā ziṇā bija savienojama ar starpkaru Latvijas tiesu iekārtas uzbūvi un darbības pamatprincipiem". ${ }^{4}$ Minētais apzīmējums - "daudzējādā", bet ne "visā" - acīmredzot attiecas uz ḷoti svarīgu tiesu varas komponentu - tiesvedību krimināllietās. Vai starpkaru perioda Latvijas Republikas kriminālprocess patiešām neatbilda “jaunlaiku prasībām”, nav šìs publikācijas priekšmets, un lai tas arī pagaidām paliek vienīgi retoriska jautājuma lìmenī.

\section{Kriminālprocesa modeḷu konverğence kā nenovēršams vēsturisks process un eklektisma ${ }^{5}$ problēma}

Raksta autors ar Rietumeiropas vēsturisko kriminālprocesa doktrīnu šeit apzīmē kopš 18. gadsimta beigām līdz pat 20. gadsimta sākumam galvenokārt Francijā, Vācijā un Krievijā tādas realizēto kriminālprocesa reformu kopējās pamatidejas, kuras varētu tikt dēvētas par kopīgu kontinentālās Eiropas kriminālprocesa tradīciju. Tā fundamentālu aksiomu veidā aizvien ir saglabājusi savu būtību par spīti globālai tā dēvētā anglosakšu kriminālprocesuālā modeḷa ietekmei.

Parasti gan literatūrā pieņemts runāt par trim, proti, tā dēvētajiem angḷu, franču un vācu, kriminālprocesa morfologiskajiem arhetipiem vai modeliem, uz kuru bāzes atsevišķās valstīs vai valstu grupās arī tika izveidotas attiecīgās leǵislatīvās tiesvedības krimināllietās formas. ${ }^{6}$ Šì raksta kontekstā autors uzskatīja par iespējamu vēl papildus izdalīt cariskās Krievijas kriminālprocesa modeli (1864. gada 20. novembra Kriminālprocesa nolikums (Уставъ уголовнаго судопроизводства)), ${ }^{7}$ kas starpkaru perioda Latvijas Republikā bija spēkā kā Kriminālprocesa likumi ${ }^{8}$ ar zināmiem grozījumiem. Savukārt cariskās Krievijas kriminālprocess kā atseviš̌ķa vēsturiska leǵislatīva tiesvedības forma veidojās gan

2 Lazdiṇš J. Tiesu varas pēctecība kā viens no valsts kontinuitātes pamatiem. Grām.: Juridiskā izglītība un kultūra: pagātnes mācības un izaicinājumi. Rīga, 2014. gada 10.-11. novembrī. Latvijas Universitātes 5. starptautiskā konference, veltīta Latvijas Universitātes Juridiskās fakultātes 95. gadadienai. Rīga: LU Akadēmiskais apgāds, 2014, 649. lpp.

3 Lazdiņš J. Krievijas impērijas 1864. gada tiesu reforma un tās nozīme Baltijas guberṇās un vēlāk Latvijā. Grām.: Tiesību efektīvas piemērošanas problemātika. Latvijas Universitātes 72. zinātniskās konferences rakstu krājums. Rīga: LU Akadēmiskais apgāds, 2014, 68.lpp.

4 Lazdin̦š J. 2017, 359. lpp.

5 Eklektika [< gr. eklektikos - 'tāds, kas izvēlas, atlasa'] - neprincipiāla, mehāniska dažādu uzskatu, teoriju, idejisko virzienu savienošana; viengabalainības trūkums. Ilustrētā svešvārdu vārdnīca. I. Andersone, I. Čerņevska, I. Kalniņa u. c. Rīga: Avots, 2005, 186. lpp.

6 Смирнов А. Модели уголовного процесса. Санкт-Петербург: Наука, 2000, с. 132.

7 Устав Уголовного Судопроизводства: свод зак. т. 16, ч. 1, изд. 1914 года: с позднейшими узаконениями, законодательными мотивами, разъяснениями Правительствующего Сената и циркулярами Министерства Юстиции. Составлен М. П. Шрамченко и В. П. Ширковым. Изд. 8-е, исправленное и дополненное. Издание неоффициальное. Рига: Давид Гликсман, 1923, xcvi, c. 1412 .

8 Kriminalprocesa likumi: Saeimas kodifikācijas nodaḷas 1926. gada izdevums. Rīga: Saeimas kodifikācijas nodal̦a, 1926, 171. lpp.; Kriminalprocesa likums. Tieslietu ministrijas Kodifikacijas departamenta 1939. gada izdevums. Rīga: Tieslietu ministrijas Kodifikācijas departāments, 1942, 208. lpp. 
tā dēvētā franču, gan vācu modeḷa ietekmē ("franču modelis ar vācu iezīmēm"9). Tādēl ir pamats uzskatīt, ka arī Latvijas Republikas starpkaru perioda kriminālprocess, lai gan nebija origināls un patstāvīgs veidojums, tomēr bija klasisks kontinentālās Eiropas kriminālprocesa modelis.

Tomēr 1917. gada boḷševiku apvērsums Krievijā (Oktobra revolūcija) un tam sekojošās reformas iepriekš vienoto klasisko kontinentālās Eiropas kriminālprocesa doktrīnu sašķēla ne tikai ideoloǵiski, bet arī principiālos tradīcijas jautājumos. Līdzīgi kā Latvijā, arī boḷševiku pārvaldītajā Krievijā zināmu laiku tika izmantots 1864. gada 20. novembra Kriminālprocesa nolikums (Уставъ уголовнаго судопроизводства) ar attiecīgām atrunām. ${ }^{10}$

Vienlaikus nepamatoti būtu apgalvot, ka turpmāk tā dēvētais padomju (sociālistiskais) kriminālprocess vairs vispār nebūtu piederīgs kontinentālās Eiropas tiesību lokam. Turklāt padomju kriminālprocesā tika saglabāts vairums tā dēvētā vācu un franču "jauktā procesa" elementu dažādās proporcijās. ${ }^{11}$ Taču padomju kriminālprocesa ārējās pazīmes bija deklaratīvums un demagoǵiskums, valsts orgānu pārspīlētā loma, procesuālo funkciju nobīde, acīmredzams kriminālvajāšanas pārsvars pār aizstāvību, procesuālo formu neelastīgums. ${ }^{12}$ Tas viss ideologiski pakāpeniski izveidojās no sākotnējām "sociālistiskās" krimināltiesvedības formām, kuras apkalpoja "proletariāta diktatūru” cīṇā ar "škiriras ienaidniekiem”, ar tai gluži vai dabiski piemîtošo pirmstiesas izmeklēšanas orgānu visvarenumu, prokurora lomas hipertrofiju, tiesas pilnvarām uzṇemties apsūdzības funkciju, iespējamību pārskatīt likumīgā spēkā stājušos tiesas nolēmumus u. c. pazīmēm,, ${ }^{13}$ turklāt jūtīgi reageèjot uz jebkurām aktuālākajām kriminālpolitikas prasībām. ${ }^{14}$ Lìdz ar to aukstā kara gados (1945-1991) padomju ideologu proponētajam Eiropas iedalījumam "Rietumu kapitālistiskajās valstīs" (страны запада, западные капиталистические странь u. tml.) un "sociālistisko zemju nometnē" (лагерь социалистических стран восточной Европь u. tml.) bija ne tikai geogrāfisks pamatojums, bet arī politiski praktiska jēga. Tādējādi padomju kriminālprocesa doktrīnu būtu nepamatoti identificēt ar Rietumeiropas valstu kriminālprocesu doktrīnu, kura pēc Otrā pasaules kara pakāpeniski evolucionēja cilvēktiesību paradigmas nozīmīguma virzienā. Lìdz ar to autora ieskatā ir pamats lietot apzīmējumu - Rietumeiropas vēsturiskā kriminālprocesa doktrīna.

Tomēr pēc neatkarības atjaunošanas 1990.-1991. gadā Latvija atgriezās pilnīgi citā Eiropā. Tās valstu kriminālprocesuālā kārtība vēsturiski vienmēr bija vairāk vai mazāk ideologiski monolīta, taču tobrīd tās pamatā fundamentālie principi nevainīguma prezumpcija, tiesības uz taisnīgu tiesu, tiesības uz aizstāvību u. c. bija ievērojami evolucionējušies. Šìs vērtības bija kḷuvušas universālas un nevarēja tikt apšaubītas nacionālo likumu līmenī. Proti, tagad jebkurai kriminālprocesuālai sistēmai pat ir pienākums nodrošināt mūsdienīgas sabiedrības ideoloǵiskās

\footnotetext{
9 Sal.: Смирнов А. 2000, с. 192-193.

10 Sk., piemēram, 1917. gada 24. novembra Tautas komisāru padomes dekrētu "Par tiesu" [Nr. 1]: О Суде. Декрет [Nr. 1] СНК РСФСР, опубликованный в «Газете Временного Рабочего и Крестьянского Правительства» 24 ноября 1917 г. История законодательства СССР и РСФСР по уголовному процессу и организации суда и прокуратуры 1917-1954 гг. Сборник документов. Под ред. С. А. Голунского. Сост. Л. Н. Гусев. Москва: Госюриздат, 1955, с. 31.

11 Смирнов А. 2000, с. 193.

12 Ibid., c. 201-202.

13 Sk. arī: Rusanovs E. Latvijas kriminālprocesa doktrīnas avotu meklējumos. Jurista Vārds, 2015, Nr. 1, 29.-30., 33. lpp.

14 Смирнов А. 2000, с. 134-135.
} 
vērtības neatkarīgi no vēsturiskām tradīcijām vai dažādu kriminālprocesuālās kultūras nesēju (angḷu, amerikāṇu, franču, vācu, krievu utt.) tehniskajiem ieradumiem. Tādā veidā viena no patstāvīgajām Rietumu kriminālprocesa modeḷu attīstības tendencēm ir to konvergence kriminālprocesuālās ideologijas līmenī, ${ }^{15}$ vienlaikus joprojām pastāvot "Eiropas tieslietu sistēmas [sadalījumam] starp divām kultūrām ${ }^{16}$ - šì atšķirība redzama gan kriminālprocesā (apsūdzošs vai meklēšanas process ${ }^{17}$ ), gan arī kriminālvajāšanas ierosināšanā (obligātuma vai diskrecionārā principa sistēma). Tomēr vēsturiskās atš̌kirības sāk izzust, jo dažādas [Eiropas Padomes] dalībvalstis aizvien vairāk tuvina savu likumdošanu un noteikumus [šiem] kopīgajiem principiem". ${ }^{18}$ Tādējādi likumdevējs pat objektīvi nemaz nevar izvairīties no zināmas kriminālprocesa model̦u eklektikas.

Arī vēsturiski raugoties, eklektikas problēma, konstruējot attiecīgos kriminālprocesa model̦us, pastāvējusi vienmēr. Ievērojamais franču kriminālists, krimināltiesībnieks un kriminālprocesuālists Renē Garo (René Garraud, 1849-1930), raksturojot pat par 19. gadsimta Eiropas valstu kriminālprocesa bāzes modeli kḷuvušo tā dēvēto 1808. gada Napoleona ${ }^{19}$ Kriminālprocesa kodeksu, ${ }^{20}$ nemaz nekautrējās no apzīmējuma "eklektisks"21 (konkretizèt visus tā iemeslus un būtību šajā rakstā nav iespējams ${ }^{22}$ ). Literatūrā (it īpaši klasiskajos krievu autoru darbos kriminālprocesā ${ }^{23}$ ) kontinentālās Eiropas kriminālprocesu tādēḷ dēvē par jaukto kriminālprocesu (franču val. - système mixte; krievu val. - смешанныци nрои,ecc).

15 Курс уголовного процесса. МГУ им. М. В. Ломоносова, Юридический факультет. 2-е изд., испр. Под ред. докт. юрид. наук., проф. Л. В. Головко. Москва: Статут, 2017, с. 125-126.

16 Anglosakšu un kontinentālās Eiropas tiesību loku tiesību sistēmas.

17 Akuzatoriālā (apsūdzības/sacīkstes) procesa forma un inkvizitoriālā (inkvizīcijas/izmeklēšanas) procesa forma. Turpmāk tekstā lietoti jēdzieni - akuzatoriāls un inkvizitoriāls. Šāda lietojuma pamatojumu šajā publikācijā nav iespējams iztirzāt.

18 Eiropas Padomes Rekomendācija Rec(2000)19 "Valsts prokuratūras loma krimināltiesiskajā sistēmā" ar skaidrojumu memorandu. (Pieṇēmusi Ministru komiteja 06.10.2000. ministru vietnieku 724. sanāksmē), 11.-12. lpp. Pieejams: https://rm.coe.int/16804aab17 [aplūkots 19.03.2019.].

19 Napoleons Bonaparts, franču imperators Napoleons I (Napoléon Bonaparte/Napoléon I er, 1769-1821).

20 Precīzāks tulkojums no fr. Code d'instruction criminelle gan būtu - Kriminālizmeklēšanas kodekss.

${ }^{21}$ Sk.: Garraud R. Précis de droit criminal. L’explication èlémentare de la partie Générale du code penal du code d'instruktion criminelle et des lois qui ont modifié ces deux codes. Onzième édition revue et corrigée. Paris: Librairie de la société du Recueil Sirey, 1912, 50 p.

22 Francijā pazīstamās Napoleona kodifikācijas sagatavošanas laikā 19. gadsimta sākumā vēsturē pirmā kriminālprocesa kodeksa mūsdienu izpratnē sastādītāji risināja sarežgīitu dilemmu: kā savienot Lielās Franču revolūcijas rezultātu ar Francijas inkvizīcijas procesa daudzu gadsimtu tradīcijām, kuras bija iemiesotas 1670. gada Luija XIV (Louis XIV, 1638-1715) Lielā Kriminālā ordonansē (Ordonnance criminelle de 1670). Rezultātā tika pieņemts lēmums, kas ietekmēja visu turpmāko kriminālprocesa attīstību Eiropā. Kodeksa sastādītāji novilka striktu institucionālu robežu starp iepriekšējo izmeklēšanu un lietas iztiesāšanu, kura tagad ir acīmredzama, taču toreiz tā nevienam nebija pazīstama. Tā radās slavenā jauktā sistēma (système mixte), kuras pamatideja bija - kopējā tiesas procesa ietvaros tā dēvēto tiesas iepriekšējo izmeklēšanu pakḷaut inkvizīcijas elementiem, bet pamatiztiesāšanu - apsūdzības-sacīkstes elementiem, atrodot saprātīgu kompromisu starp abiem modeḷiem. (Курс уголовного процесса. МГу им. М. В. Ломоносова, Юридический факультет. 2-е изд., испр. Под ред. докт. юрид. наук., проф. Л. В. Головко. Москва: Статут, 2017, с. 137-138.)

23 Розинъ Н. Н. Уголовное судопроизводство: пособіе къ лекціямъ Н. Н. Розина. 4-е изд., пересмотр. Рига: Давид Гликсман, 1924, 597 с. (Розинъ Н. Н. Уголовное судопроизводство: пособіе къ лекціямъ Н. Н. Розина. С.-Петербург, 1914, 546 с.); Случевскій В. Учебникъ русскаго уголовнаго процесса: Судоустройство - судопроизводство. Изд. четвертое, дополн. и исправл. С-Петербургъ: Типографія М. М. Стасюлевича, 1913, XIII, 670 с.; Фойиницкій И. Я. Курсь Уголовнаго Судопроизводства. Изд. Четвертое. Томъ I. С-Петербургъ: Типография т-ва “Общественная Польза”, 1912, с. 566 u.c. 
Līdzīgi, raksturojot būtiskāko faktoru, kas ietekmēja vācu tautas vēsturi, dzīvi un pieredzi 19. gadsimta pirmajos piecpadsmit gados un kas vienlaicīgi ielika pamatu modernajai Vācijai, tajā skaitā reformētajam kriminālprocesam, viens no ievērojamākajiem vācu vēsturniekiem, Tomass Niperdejs (Thomas Nipperdey, 1927-1992), savas grāmatas "Vācu vēsture. 1860-1866"24 pašā pirmajā teikumā patētiski rakstīja: "Iesākumā bija Napoleons", ${ }^{25}$ bet fonā tam visam bija "karš un iekarošana, izlaupišana un apspiešana, impērija un jauna kārtība”. ${ }^{26}$ Arī profesors J. Lazdiņš pamatoti atzīst, ka tiesu reformai Krievijas impērijā 19. gadsimta 60. gados par paraugu noderēja Eiropas valstu un pašas Krievijas impērijas pieredze, turklāt sliecoties uzskatīt, ka starp Eiropas valstīm dominējošā nozìme tiesu reformas kontekstā bija Francijas pieredzei ar tiesu varu saistītos aspektos. ${ }^{27}$

\section{Kriminālprocesa vēsture kā reformu palīginstruments}

Tādējādi jāsecina, ka zināma eklektika pati par sevi nevarētu būt problēma, veidojot procesuālo formu konstrukcijas uz ideoloǵiski monolīta pamata.

Taču Latvijai pēc neatkarības atjaunošanas bija papildu grūtības, proti, jāpārvar teorijā un praksē iesakņojušies padomju okupācijas perioda (1940-1941; 1944-1991) kriminālprocesa arhetipi ${ }^{28}$ kā svešas kriminālprocesuālās ideoloǵijas elementi.

Atsakoties no Latvijas Republikas starpkaru perioda Kriminālprocesa likumu reanimēšanas, jaunā kriminālprocesuālā kārtība līdz to bija jāveido saskaņā ar kādu no Rietumu tiesību loka kultūras tradīcijām, jo bija jāreformē kriminālprocesa likumi, kas bija autoritāra politiskā režīma perioda normatīvie akti un kas realizēja inkvizitoriāla tipa tiesvedību, kura vienīgi ārēji tika ietērpta dažās sacīkstes formās.

Entuziasms un patiesas cerības uz pārmaiņām arī motivēja Latvijas juristus lūkoties anglosakšu kriminālprocesa modeḷa virzienā, cenšoties labāko no tā implementēt nacionālajos likumos. Acīmredzot, intuitīvi cenšoties padomju kriminālprocesa trūkumus kompensēt ar aizgūtiem un līdz tam neaprobētiem kriminālprocesuāliem mehānismiem, likuma "Par tiesu varu"29 tēvi atjaunotās Latvijas kriminālprocesā sākotnēji iedibināja sacīkstes tiesvedỉbas principu. ${ }^{30}$ Pēc tam pilnīgi loǵiski un secīgi jaunā kriminālprocesa likuma koncepcijas autors nepārprotami piedāvāja atteikties no kontinentālās Eiropas kriminālprocesa doktrīnas "svētās govs" - materiālās patiesības noskaidrošanas principa. ${ }^{31}$ Loğiski un secīgi

${ }^{24}$ Nipperdey T. Deutsche Geschichte. 1800-1866. Bürgerwelt und starker Staat. 5., durchges. Aufl. München: Verlag C. H. Beck, 1991, S. 826.

25 "Am Anfang war Napoleon." Ibid., S. 11.

26 "Krieg und Eroberung, Ausbeutung und Unterdrückung, Imperium und Neuordnung" (Nipperdey T. 1991, S. 11).

${ }^{27}$ Lazdiņš J. 2014, 62. lpp.

${ }^{28}$ Arhetips [gr. archetypon < archē 'sākums' + typos 'forma, pirmveids, paraugs']. Ilustrētā svešvārdu vārdnīca. I. Andersone, I. Čerņevska, I. Kalniņa u. c. Rīga: Avots, 2005, 68. lpp. Šeit domāti kā slēpti un stabili mehānismi jeb faktori, kas ne tikai ietverti pozitivizētajos normatīvajos aktos, bet arī būtiski ietekmē šo normu piemērotāju psiholoǵiju.

${ }^{29}$ Likums "Par tiesu varu”: LV likums. Latvijas Republikas Augstākās Padomes un Valdības Ziṇotājs, 14.01.1993., Nr. 1/2.

${ }^{30}$ Zemrībo G. Likums "Par tiesu varu" un civilprocesuālā likumdošana. Jurista Vārds, 2018, Nr. 4, 9.-14. lpp.

31 Skrastiņš J. Par mūsdienīgu kriminālprocesu Latvijā. Jurista Vārds, 2001, Nr. 7-9. 
tādēḷ, ka saskaṇā ar minēto doktrīnu pēdējā ir noskaidrojama vienīgi objektīvās izmeklēšanas cel̦ā tiesvedības gaitā, taču no tās vismaz formāli Latvija jau bija atteikusies. Taču konsekventi šì ideja diemžēl netika realizēta. Iemesls tam acīmredzot ir ne tikai birokrātiskās infrastruktūras pretestība, bet arī objektīva neiespèjamība padomju kriminālprocesā, kuru būtiskā daḷā Latvija turpināja ekspluatēt (un arī joprojām to dara), saskatīt tādu vēl 20. gadsimta 20. gados notikušu transformāciju, kas principiāli padarīja par neiespējamu Latvijas Republikā nedz atjaunot starpkaru perioda Kriminālprocesa likumus, nedz implementēt kādu no klasiskajiem kontinentālās Eiropas kriminālprocesiem (piemēram, 1974. gadā reformèto Vācijas kriminālprocesa modeli), nedz arī, protams, ieviest sacīkstes (šĩ vārda īstajā nozīmē) modeli.

Rezultātā pēc svārsta principa no patiesa sacìkstes procesa iedīgḷiem Latvijas kriminālprocess nonāca punktā, ko varētu apzīmēt par "padomju kriminālprocesu ar cilvēcisku seju”, jo ignorēta tika cita kontinentālās Eiropas kriminālprocesa doktrīnas aksioma - ja arī notiek iepriekšèjā izmeklēšana (kā, piemēram, joprojām Francijā), tā ir tiesas funkcija. Ja tā nenotiek (kā, piemēram, Vācijā kopš 1974. gada), tad pirmstiesas process ir vienīgi "prokurora izziṇa”. Taču atškiririba starp izzin̦as un iepriekšèjās izmeklēšanas institūtiem Rietumeiropas tradīcijā ir fundamentāla.

Reformētais Latvijas "pirmstiesas kriminālprocess" teorētiski pēc būtības arī ir vienīgi "prokurora izziṇa” ar visām no tā tālāk izrietošajām doktrinārajām konsekvencēm, piemēram, kas nepiel̦auj būtībā šādas izteiktas "netiesas stadijā" iegūto pierādījumu fetišismu, ${ }^{32}$ izskatot lietu tiesā, kā tas notika padomju kriminālprocesā un kā joprojām notiek Latvijā. Šāda aplama izpratne l̦auj apšaubìt arī dažu citu Kriminālprocesa likumā ${ }^{33}$ ietverto noregulējumu atbilstību Latvijas Republikas Satversmei, piemēram, kas attiecas uz faktiski "prokurora izziņas" (pirmstiesas procesa) stadijā notiekošo procesu par noziedzīgi iegūtu mantu, ${ }^{34} \mathrm{kad}$ šajā "netiesas stadijā” būtiskā daḷā tiek uzurpētas tiesas funkcijas. Kaut kas tamlīdzīgs nav iedomājams Vācijas kriminālprocesā.

Lìdz ar to Latvijas kriminālprocesa reformu gaita pati par sevi izvērtās visnotal pretrunīga, uz to raksta autors jau iepriekš ir vairākkārt norādījis, ${ }^{35}$ proti, likumdevējs, nekonsekventi reformējot okupācijas perioda kriminālprocesuālo kārtību, nepiel̦aujami izšḳīās par kriminālprocesa modeli uz padomju kriminālprocesa iepriekšējās izmeklēšanas institūta izpratnes bāzes.

Lai arī iztiesāšanas tiesā stadiju likumdevējs izveidoja ar vairākām pietiekami nepārprotami izteiktām anglosakšu kriminālprocesa pazīmēm, tomēr pamatā tika saglabāta pilnīgi izkropḷota kontinentālās Eiropas kriminālprocesa versija

${ }^{32}$ Fetišisms [fr. fétichisme] - priekšmeta, kam piedēvē maǵiskas, pārdabiskas īpašības, nekritiska cieṇa un dievināšana. Ilustrētā svešvārdu vārdnīca. I. Andersone, I. Čerņevska, I. Kalniņa u. c. Rīga: Avots, 2005, 224. lpp.

${ }^{33}$ Kriminālprocesa likums: LV likums. Pieņemts 21.04.2005. Latvijas Vēstnesis, 2005, Nr. 74. Pieejams: https://www.vestnesis.lv/ta/id/107820.

34 Sk. un sal.: Kriminālprocesa likuma 59. nodal̦a.

35 Sīkāk sk.: Rusanovs E. Latvijas kriminālprocesa doktrīnas avotu meklējumos. Jurista Vārds, 2015, Nr. 1, 28.-35. lpp.; Rusanovs E. Daži iebildumi par jautājumiem, kas skar tiesu kompetenci apsūdzības trūkumu novēršanā. Jurista Vārds, 2015, Nr. 21, 20.-22. lpp.; Rusanovs E. Turpinot par iebildumiem jautājumos, kas skar tiesu kompetenci apsūdzības trūkumu novēršanā. Jurista Vārds, 2015, Nr. 27, 22.-31. lpp.; Rusanovs E. Procesa par noziedzīgi iegūtu mantu regulējums Kriminālprocesa likumā. Jurista Vārds, 2016, Nr. 1, 24.-31. lpp.; Rusanovs E. Patvaḷas aizliegums kriminālprocesā. Grām.: Kriminālprocesa likumam - 10. Pagātnes mācības un nākotnes izaicinājumi. Prof. Dr. iur. Ā. Meikališas zinātniskā redakcijā. Rīga: Latvijas Vēstnesis, 2015, 170.-187. lpp. 
(ar to galvenokārt domājot objektīvās izmeklēšanas principa neesamību un tiesneša salīdzinošo pasivitāti). Tādēl Latvijas kriminālprocesa norisē ik uz soḷa var nonākt gluži neatrisināmās doktrināri teorētiskās pretrunās. Iespējams, tieši tādēḷ savlaicīgs ekskurss kriminālprocesa vēsturē būtu bijis visnotaḷ noderīgs instruments brīžiem nesavietojamas eklektikas ${ }^{36}$ novēršanai pašreizējā Kriminālprocesa likumā.

Tādējādi reformu gaitā netika ņemts vērā, ka, neraugoties uz nemitīgu un ar vispārzināmo inkvizitoriālās un akuzatoriālās procesuālo formu iedabu savstarpējo pretestību iezīmētu likumdošanas procesu ilgstošā vēstures periodā, ${ }^{37}$ "klasiskajās" kontinentālās Eiropas valstīs tik un tā joprojām pastāv tādas objektīvas kriminālprocesuālo tiesību tradīcijas īpatnības, kas izpaužas tieši teorētiskajā plaknē. Šo formu atšķirīgo pazīmju noteikšana pašsaprotami nav atvasināma vienīgi no intelektuālām konstrukcijām. Šo rezultātu drīzāk var sasniegt ar šis tradīcijas vēsturiskās būtības izpratni un uztveres gatavību. ${ }^{38}$

Turpinājumā tikai viens piemērs, kas norāda uz sistēmisku kḷūdu, Latvijas kriminālprocesā saglabājot padomju kriminālprocesa iepriekšèjās izmeklēšanas institūta izpratni.

\section{Iepriekšējās izmeklēšanas institūta izpratne padomju kriminālprocesā: implementācijas vēsturiskā secỉba Latvijas kriminālprocesā}

Kā jau tika minēts, pieḷaujot atkāpi no “iepriekšējā izmeklēšana kā tiesas funkcija” institūta, kas ir viena no fundamentālākajām kontinentālās Eiropas kriminālprocesa doktrīnas vērtībām un kas pastāvēja Latvijas Republikā arī starpkaru periodā, tika izdarìta ne tikai milzịga teorētiska un sistēmiska kḷūda. Pēc būtības tika saglabāta kontinentālās Eiropas kriminālprocesuālo tiesību tradīcijai pilnīgi sveša izpratne par “iepriekšējās izmeklēšanas” institūtu, kas 20. gadsimta 20. gados tieši ideologiisku apsvērumu dēl padomju kriminālprocesā tika likvidēts.

Kā trāpīgi izteicās profesors Aleksandrs Smirnovs (Александр Смирнов), pat Napoleons neatḷāvās šādu ekstravaganci - no sākuma tieši pakḷaut tiesas institūciju (izmeklēšanas tiesnesi) prokuratūrai, bet pēc tam atteikties no iepriekšējās izmeklēšanas tradicionālajā izpratnē, proti, no iepriekšējās izmeklēšanas kā tiesas darbības. Šis process iesākās vēl 1922. gada 25. maija pirmajā padomju Kriminālprocesa kodeksā un tika pabeigts ar KPFSR Viskrievijas Centrālās izpildkomitejas un Tautas komisāru padomes 1928. gada 3. septembra lēmumu un PSRS Centrālās izpildkomitejas 1929. gada 30. janvāra lēmumu. 39 Šo "traǵisko notikumu” rezultātā padomju kriminālprocesā notika klasiskās iepriekšèjās izmeklēšanas bojāeja,

${ }^{36}$ Eklektiku izraisīja Kriminālprocesa likuma nepiel̦aujama salipināšana pēc Vikipēdijas (Wikipedia) principa (minētā projekta dalībnieku brīvprātīgi veidoti raksti, kurus ikviens, kam ir nodrošināta pieeja, var labot).

37 Dezza E. Geschichte des Strafprozessrechts in der Frühen Neuzeit. Eine Einführung. eBook. Berlin: Springer, 2017, S. 1. Tulkojumā no itāliešu valodas vācu valodā tiek lietoti jēdzieni "inquisitorisch" un "akkusatorisch". Arī citviet literatūrā vācu valodā ir sastopams lietojums: "inquisitorisch" - "akkusatorisch".

${ }^{38}$ Ibid., S. 1.

39 Собрание узаконений и распоряжений рабочего и крестьянского правительства РСФСР. РСФСР, 1928,117, с. 733; Собрание законов и распоряжений рабоче-крестьянского правительства Союза Советских Социалистических Республик, 1929, 3, с. 106. 
un tā pārvērtās par "prokurora izziṇu”, kura bija apveltīta ar uzurpētām tiesas funkcijām. ${ }^{40}$

Tad secīgi šì izpratne varmācīgi tika implementēta Latvijas kriminālprocesā pēc tās okupācijas (1940), ${ }^{41}$ un tāda ir saglabājusies vēl aizvien.

Līdz ar to okupētajā un anektētajā Latvijā kā toreizējās Padomju Savienības sastāvdaḷā pilnībā sāka darboties padomju kriminālprocesa doktrīna ar visiem klasiskās jeb vēsturiskās kontinentālās Eiropas kriminālprocesa doktrīnas izkroplojumiem.

Autora ieskatā, saglabājot reformētajā Latvijas kriminālprocesā šādu svešķermeni, tas nevar atbilst jaunlaiku prasībām.

\section{Kopsavilkums}

1. Tiesu varas principi, kādi pastāvēja starpkaru Latvijas Republikā (1918-1940), pēc neatkarības atjaunošanas (1990-1991) tika pārṇemti tikai daḷēji. Reformējot kriminālprocesuālo kārtību, likumdevējs nebalstījās uz starpkaru Latvijas tiesību tradīciju, uzskatot, ka tā neatbilst jaunlaiku prasībām.

2. Pateicoties monolītai kriminālprocesuālajai ideologijai, kuras pamatā ir fundamentāli cilvēktiesību principi - nevainīguma prezumpcija, tiesības uz taisnīgu tiesu, tiesības uz aizstāvību u. c. -, anglosakšu un kontinentālās Eiropas kriminālprocesu model̦iem piemīt konvergences tendences. Līdz ar to arī reformètā kriminālprocesuālā kārtība Latvijas Republikā ir izteikti eklektiska ar tendenci tomēr saglabāt kontinentālās Eiropas kriminālprocesuālo tiesību tradīciju. Cits citu izslēdzošu principu mijiedarbība var izraisīt tiesu sistēmas efektivitātes trūkumus.

3. Kontinentālās Eiropas kriminālprocesuālo tiesību doktrīnai jeb tradīcijai joprojām saglabājas zināmas aksiomātiskas vērtības, kurām ir arī vēsturisks un teorētisks pamatojums. Latvijā tam netika pievērsta vajadzīgā uzmanība.

4. Līdz ar to reformu gaitā Latvijas Republikā tika saglabāta pēc padomju okupācijas (1940) implementētā klasiskās kontinentālās Eiropas kriminālprocesuālo tiesību tradīcijai pilnīgi sveša izpratne par "iepriekšèjās izmeklēšanas" institūtu. Šāda tiesību tradīcijas vērtība - "iepriekšējā izmeklēšana kā tiesas procesa sastāvdaḷa un funkcija” - pastāvēja arī Latvijas Republikā starpkaru periodā. Saglabājot reformētajā Latvijas kriminālprocesā šādu sveškçermeni, tas nevar atbilst jaunlaiku prasībām.

40 Смирнов А. 2000, с. 193-194.

41 PSR Savienības Augstākās Padomes Prezidija 1940. gada 6. novembra dekrēts par KPFSR kriminālās, civīlās un darba likumdošanas pagaidu piemērošanu Lietuvas, Latvijas un Igaunijas Padomju Sociālistisko Republiku teritorijās. Padomju Augstākās Padomes Ziņotājs, 18.11.1940., Nr. 46; Latvijas PSR Tautas Komisāru Padomes 1940. gada 25. novembra paziņojums par KPFSR likumu (kodeksu) piemērošanu Latvijas PSR teritorijā. Latvijas PSR Augstākās Padomes Prezidija Ziņotājs, 26.11.1940., Nr. 74; [1922. gada 25. maija] KPFSR Kriminālprocesa kodekss. Ar pārgrozījumiem līdz 1940. gada 15. novembrim. Oficiāls teksts ar pielikumiem un sistematizētiem materiāliem pantu kārtībā. Latvijas PSR Tieslietu Tautas Komisāriāta Kodifikācijas daḷas tulkojums. Latvijas PST Tieslietu Tautas Komisāriāta izdevums. Rīga, 1940, 202. lpp.; 1961. gada 6. janvāra likums Par Latvijas PSR kriminālprocesa kodeksa apstiprināšanu. Latvijas PSR Augstākās Padomes un Valdības Ziṇotājs, 1961, Nr. 3 [spēkā no 01.04.1961.]; Latvijas Padomju Sociālistiskās Republikas Kriminālprocesa kodekss. Rìga: Latvijas Valsts izdevnieciba, 1961, 132. lpp. 